\title{
Circumstantial evidence of life history events in loricate choanoflagellates
}

\section{Thomsen, Helge Abildhauge; Østergaard, Jette Buch}

\section{Published in:}

European Journal of Protistology

Link to article, DOI:

10.1016/j.ejop.2016.12.004

Publication date:

2017

Document Version

Version created as part of publication process; publisher's layout; not normally made publicly available

Link back to DTU Orbit

Citation $(A P A)$ :

Thomsen, H. A., \& Østergaard, J. B. (2017). Circumstantial evidence of life history events in loricate choanoflagellates. European Journal of Protistology, 58, 26-34. https://doi.org/10.1016/j.ejop.2016.12.004

\section{General rights}

Copyright and moral rights for the publications made accessible in the public portal are retained by the authors and/or other copyright owners and it is a condition of accessing publications that users recognise and abide by the legal requirements associated with these rights.

- Users may download and print one copy of any publication from the public portal for the purpose of private study or research.

- You may not further distribute the material or use it for any profit-making activity or commercial gain

- You may freely distribute the URL identifying the publication in the public portal 


\section{Accepted Manuscript}

Title: Circumstantial evidence of life history events in loricate choanoflagellates

Author: Helge Abildhauge Thomsen Jette Buch Østergaard

PII: $\quad$ S0932-4739(16)30166-3

DOI: $\quad$ http://dx.doi.org/doi:10.1016/j.ejop.2016.12.004

Reference: $\quad$ EJOP 25474

To appear in:

Received date: $\quad$ 19-9-2016

Revised date: $\quad 30-11-2016$

Accepted date: $\quad$ 20-12-2016

Please cite this article as: Thomsen, Helge Abildhauge, Østergaard, Jette Buch, Circumstantial evidence of life history events in loricate choanoflagellates.European Journal of Protistology http://dx.doi.org/10.1016/j.ejop.2016.12.004

This is a PDF file of an unedited manuscript that has been accepted for publication. As a service to our customers we are providing this early version of the manuscript. The manuscript will undergo copyediting, typesetting, and review of the resulting proof before it is published in its final form. Please note that during the production process errors may be discovered which could affect the content, and all legal disclaimers that apply to the journal pertain. 


\section{Circumstantial evidence of life history events in loricate choanoflagellates}

Helge Abildhauge Thomsen ${ }^{\mathrm{a}, *}$ and Jette Buch Østergaard ${ }^{\mathrm{b}}$

${ }^{a}$ National Institute of Aquatic Resources, Technical University of Denmark, Charlottenlund, Denmark,

${ }^{\mathrm{b}}$ Nørrebrogade 52a $5^{\text {th }}, 2200$ Copenhagen N, Denmark

*Corresponding author: DTU Aqua, Jægersborg Allé 1, 2920 Charlottenlund, Denmark; Fax: +4535883333.

E-mail address: hat@aqua.dtu.dk (H. A. Thomsen) 


\begin{abstract}
Sex is found in all major eukaryotic groups of organisms. It has been known for some time that the choanoflagellates also possess the genes involved in meiosis and a full sexual cycle was also recently accounted for in Salpingoeca rosetta. With reference to the loricate choanoflagellates the current status is that only circumstantial evidence, from wild material of Bicosta spinifera, exists in favour of documenting division patterns that go beyond plain asexual division, and that has the potential to represent stages in a sexual life cycle. Here we present further evidence from wild material documenting possible morphotype changes that might similarly indicate the existence of complex life cycles. In this particular case, it revolves around the existence of so-called ‘combination loricas' (i.e. two loricas that occur physically united), representing consistent species combinations from the genera Acanthocorbis and Stephanoeca.
\end{abstract}

Keywords: Acanthocorbis; Combination lorica; Life history; Loricate choanoflagellates; Stephanoeca 


\section{Introduction}

Evidence for sex is found in all major eukaryotic groups of organisms, and the phylogenetic ubiquity of sex emphasizes its general importance when it comes to long-term survival of species. Life cycle studies must therefore be pursued because they are 'fundamental to the development of a species-focused biological oceanography that aims to understand how the astonishing diversity of planktonic organisms structure the oceans’ (Dassow and Montresor, 2011).

Choanoflagellates possess conserved eukaryotic genes involved in meiosis and Carr et al. (2010) suggested that undiscovered sexual cycles are likely to occur. Levin and King (2013) recently demonstrated that Salpingoeca rosetta can switch ploidy under laboratory conditions as part of a sexual life cycle that involved several morphotypes.

It is often complicated or even impossible to identify and preserve the various both sexual and non-sexual life cycle phases of an organism when relying on classical plankton observation methods applicable to wild material (Dassow and Montresor, 2011). Even when it comes to organisms that have been established in culture it may also never be possible to induce phase transitions through manipulations of the medium used and prey sources, or exposure to varied combinations of basic environmental parameters (e.g. temperature and salinity). In the case of loricate choanoflagellates we are still lacking behind in terms of providing conclusive evidence for the existence of complex life histories that may or may not involve sex both from nature and from any kind of culture established. There are, however, circumstantial evidence (Thomsen and Larsen, 1992; Thomsen et al., 1997) from the examination of wild material of tectiform species suggesting that loricate choanoflagellates do occasionally deviate from strict asexual division, where one individual prior to mitotic division produces a complete set of costal strips that exactly mirrors that of the parent cell 
lorica, and that is subsequently utilized by one cell from the newly divided parent cell to assemble a lorica of its own (see e.g. Leadbeater, 2015).

Thomsen and Larsen (1992) showed with reference to Southern Ocean populations of Bicosta spinifera (Throndsen, 1970) Leadbeater, 1978, that these occurred with pronounced site-specific bimodal differences in e.g. overall lorica length. The frequent finding of small specimens (15 $\mu \mathrm{m}$ range) that prepared themselves for an abrupt up to 8-fold increase in size (Thomsen and Larsen, 1992; loc. cit. Figs 24-25) was interpreted as clear evidence in favour of a deviation from the standard asexual division pattern that is indicative of the existence of a polymorphic life history in this species. Subsequent Antarctic material of the same species (Thomsen et al., 1997) contributed further evidence in favour of the existence of complex life histories within loricate choanoflagellates. Small specimens of B. spinifera in preparation for cell division (Thomsen et al., 1997; loc. cit. Figs 43-45) were thus found to accumulate bundles of a diverging type of costal strips, which in plain numbers by far exceed the number of strips needed to produce an exact copy of the Bicosta lorica (7 costal strips), indicative of an imminent dramatic change in lorica morphology over the time span of just one generation. It was unfortunately not possible based on costal strip morphology and dimensions to predict the resulting lorica type.

Here we add further circumstantial evidence from examinations of wild material from West Greenland and the Kattegat (the transition area between the North Sea and the Baltic Sea) that is substantiating the existence of complex life cycles in loricate choanoflagellates that involve multiple morphotypes. While it is fully appreciated that the evidence provided here only contributes yet another small step towards a more coherent perspective on loricate choanoflagellate life histories, we also believe that a stepwise publication effort on this theme is the only way forward, because a more complete picture may eventually have to be pieced 
together by several independent and fortuitous observations of naturally occurring phenomena.

\section{Material and Methods}

West Greenland (Disko Bay) water samples were collected 16 August - 5 September 1990 from the R/V "Porsild" from 13 stations (0-200m) near the Arctic Station, Qeqertarsuaq (Fig. 1A). Additional sampling took place in coastal Danish waters (Kattegat) at a single station ('Buoystation’; Fig. 1B) throughout the period October 1988 to October 1989 (Thomsen, 1992).

The protocol for processing water samples for both the transmission electron microscope (TEM) and the light microscope (LM) were similar on all sampling occasions (see Moestrup

and Thomsen, 1980). The nanoplankton community was concentrated for further processing by means of either centrifugation of a prefiltered (usually $20 \mu \mathrm{m}$ ) water sample or centrifugation of prefiltered material resuspended from an initial filtration of cells on top of e.g. a $1 \mu \mathrm{m}$ Nuclepore filter. Small droplets of cells from the resuspended final pellet of material were - irrespective of the initial concentration procedure - placed on either carbon coated grids for the TEM or rinsed coverslips for the LM. Cells were subsequently fixed for ca. 30 seconds in the vapour from a 1-2\% aqueous solution of $\mathrm{OsO}_{4}$. After drying both grids and coverslips were carefully rinsed in distilled water to remove salt crystals. Grids were shadowcast with either $\mathrm{Au} / \mathrm{Pd}$ or $\mathrm{Cr}$ prior to the examination in JEOL electron microscopes property of the Botanical Institute at the Univ. of Copenhagen. Coverslips intended for the LM examinations and enumerations (relative abundances) were air mounted upside down in order to render possible the use of a x100 objective. 


\section{Results}

\section{West Greenland combination loricas (Acanthocorbis campanula/Stephanoeca apheles)}

The Disko Bay material comprised a hitherto unknown type of mechanically paired loricas ('combination loricas'). A "double" lorica (Figs 2-6) that consistently combines two different genera was observed 33 times in total from both LM and TEM. The anteriormost lorica has morphological and numerical features in common with Stephanoeca apheles Thomsen in Thomsen et al., 1991 (Fig. 7), while the posteriorly located lorica is similar to Acanthocorbis campanula (Espeland, 1986) Thomsen, 1991 (Figs 9-10). A protoplast, if present, is always located in the Stephanoeca-part of the combined loricas. Combination loricas were observed (Fig. 8) only in the uppermost part of the water column (0-50 m). Acanthocorbis campanula and S. apheles additionally occurred as solitary cells (Figs. 7, 9-10). Morphological characteristics, lorica dimensions and numerical aspects of solitary cells as well as specimens forming part of combination loricas are presented below (see also Table 1).

\section{Stephanoeca apheles, solitary cell (Fig. 7)}

The West Greenland material is similar to the Danish type material (Thomsen et al., 1991) except for the number of longitudinal costae (12-15 as opposed to 14-16 in the type material). The lorica measures ca. $14 \mu \mathrm{m}$ x $4 \mu \mathrm{m}$ and consists of two lorica chambers delimited by a waist. The protoplast is located in the posterior lorica chamber. Solitary cells of Stephanoeca apheles were rarely encountered during the light microscopical examination of material from 1990 (Fig. 8). The species has not previously been recorded from polar regions.

\section{Acanthocorbis campanula, solitary cells (Figs 9-10)}

The West Greenland material differs from the Norwegian type material (Espeland and Throndsen, 1986) in possessing more longitudinal costae (10-12 as opposed to 8-10). The 
Greenland cells additionally have no pedicel and a small variation in the appearance of the species diagnostic junctions between anterior longitudinal and transverse costal strips. The "triangular" joints (Fig. 9) caused by the tilted positioning of anterior transverse costal strips (that each span two interspaces between longitudinal costae) are thus more pronounced than in the type material and in this respect similar to cells from California (Thomsen et al., 1991). Acanthocorbis campanula undergoes tectiform division (Fig. 10). The solitary form of $A$. campanula was among the Disko Bay surface water community dominants during the period sampled (5.9\% of all cells identified). The vertical distribution of A. campanula and the relative abundances calculated appear from Fig. 8. In some surface samples one third of all loricate choanoflagellates were identified as cells of A. campanula.

\section{Combination loricas (Figs 2-6)}

With respect to general lorica features, numerical aspects and dimensions of the individual costal strip there is no significant difference between solitary specimens of $A$. campanula and S. apheles and those that form part of a combination lorica (Table 1). Bundles of accumulated costal strips are frequently observed in the collar region of the protoplast located in the posterior S. apheles lorica chamber (Figs 3-4) indicating that the cell is preparing for asexual division.

It is a characteristic feature of the empty A. campanula loricas that these are in some cases formed by exceptionally heavily silicified costal strips (Figs 2-3) whereas the S. apheles costal strips from the lorica above are thin rods of a type that is more generally observed among loricate choanoflagellates. In other cases (e.g. Fig. 6), the costal strips are of a more uniform thickness in both loricas forming part of the combination lorica.

The mutual connection between the two types of loricas is not clear, although it appears that the A. campanula lorica is external. 
Combination loricas were found in three samples only (Fig. 8).

\section{Kattegat combination loricas (Acanthocorbis haurakiana/Stephanoeca cauliculata)}

The Kattegat material sampled as an integrated part of the 'HAV90' project (Thomsen, 1992) comprised combination loricas analogous to those described above from West Greenland. The combination loricas (Figs 11-13) here comprises Acanthocorbis haurakiana Thomsen, 1991 (empty lorica posteriorly positioned) and Stephanoeca cauliculata Leadbeater, 1980 (anteriormost lorica with a protoplast). Combination loricas occurred in low numbers during the period May-July 1989.

Solitary cells of Acanthocorbis haurakiana (Figs 14-15) occurred in low numbers alongside the combination loricas. They are identical to the Californian type material in most diagnostic features. However, the lorica height $(15-20 \mu \mathrm{m})$ is slightly less than in the type material (20-25 $\mu \mathrm{m})$, and it also appears that the Kattegat material has consistently six longitudinal costae as opposed to seven in the Californian type material. Costal strip dimensions are similar. A reduction in number of longitudinal costae towards the posterior cell end, which was a characteristic feature of Californian cells, is not mirrored here. The variability noted easily falls within what is typically encountered when comparing specimens of the same species across vast geographic ranges.

A few solitary specimens of $S$. cauliculata were also observed (Figs 16-17). There is reasonably good agreement in morphological details and dimensions when comparing these cells with the Northern France type material (Leadbeater, 1980). The only differing feature that needs to be highlighted is the absence of a well-defined stalk in Danish specimens. The cell illustrated in Fig. 17 has a short posterior stalk (ca. $4 \mu \mathrm{m}$ ), however, cells from the type locality, a seawater inlet at La Forêt near Concarneau, sometimes carried stalks that were up to $30 \mu \mathrm{m}$ long. The length of a posterior appendage is not generally considered a conservative 
feature in as much as it is known to vary considerably, and to depend e.g. on physical aspects of the prevailing growth conditions. A posterior stalk both serves as a point of attachment for the cell but also helps lifting the cell away from competing surface dwelling organisms to provide a competitive gain. An environment, such as the type locality, which is near coastal and likely rich in all types of surfaces that can serve as anchoring points for specimens of $S$. cauliculata, will on the average have a larger share of long stalked specimens when compared to a more open water site as the one sampled here.

\section{Discussion}

The West Greenland material is unsurpassed both in terms of clarity of the combination lorica species associations, and also when considering the number of occurrences of combination loricas in the material. The Kattegat combination loricas may in fact easily have been overlooked if we had not been vigilant when re-examining our loricate choanoflagellate material at large, following the recording of this phenomenon from West Greenland waters. The Kattegat material, despite its shortcomings, both in terms of cell preservation and details, as well as the mere number of occurrences, yet adds an important dimension to the whole concept, in as much as it repeats the exact same combination of genera as was previously encountered in West Greenland waters, yet with a novel species combination. This fact in correlation with the frequent occurrences of combination loricas in West Greenland waters conclusively rules out the possibility that we are merely observing a random phenomenon.

Our working hypothesis is rather that we are here observing heteromorphic phases in the life history of a loricate choanoflagellate species that involves a change from an Acanthocorbis type of lorica (lower empty cell) to a Stephanoeca type of lorica (upper cell with protoplast). The basic concept is thus reminiscent of what was previously reported in $B$. spinifera from Antarctic waters (Thomsen et al., 1997), with the exception that here the new 
lorica to be formed was only evident from bundles of morphologically divergent costal strips (>50) that vastly surpassed what is needed to construct a $B$. spinifera lorica (7). No double loricas were observed in the Antarctic material. However, a small B. spinifera specimen somewhere attached to a lorica comprising in excess of 50 costal strips might also be hard to detect. The underlying assumption is thus that an individual loricate choanoflagellate species has the genetic pathways required to generate loricas with the diagnostic characteristics of two different genera. Based on the B. spinifera evidence provided (Thomsen et al., 1997) it appears that the cell, while still positioned in the B. spinifera lorica, can somehow initiate the production of an alternate type of lorica. When combining, and extrapolating this evidence with observations from the Acanthocorbis/Stephanoeca combination loricas provided here, it appears most likely, with reference to the consistently empty Acanthocorbis loricas, that the cell producing the alternate type of costal strips also assembles these without prior cell division.

We can only speculate about what might trigger such a dramatic and abrupt switch in lorica morphotype. Sex through mating and a ploidy shift are likely events that could indeed manifest themselves this dramatically. Sex is often induced when the fitness of an asexually reproducing individual declines. The need for sexual reproduction also in loricate choanoflagellates can be no different from what applies to other groups of protists, and is similarly likely to be provoked by changes in environmental parameters such as temperature, salinity, nutrient levels and prey availability and composition. The $1 \mathrm{~N}$ and $2 \mathrm{~N}$ cells of the presumed haplo-diplontic loricate choanoflagellate are accordingly likely to be physiologically distinct, which in turn allows a 'species' to occupy different ecological niches and thus generate evolutionary momentum.

When evaluating the case presented here for the existence of multiple morphotypes within a single acanthoecid species, it is relevant to bear in mind the repeated findings of multiple 
morphotypes within species from the Craspedida. The life history of Salpingoeca rosetta thus comprises at least five different cell types (Dayel et al., 2011; Levin and King, 2013).

It is pertinent here to draw a parallel to other groups of unicellular protists, i.e. the coccolithophores, which provide excellent documentation of an alternation between haploid and diploid generations manifested through very distinct heteromorphic phases (Kamptner, 1941; Parke and Adams, 1960, Thomsen et al., 1991, Billard, 1994). Ongoing efforts towards unveiling as many as possible of these heterococcolithophore (2n) -holococcolithophore (1n) life histories has an immediate, however, temporarily complicating impact on the nomenclatural framework established for these organisms. While name changes are bound to occur and new terminology developed to identify phases, the basic concepts with respect to identifying coccolithophore morphotypes yet remain intact.

If future research demonstrates that it is a shared feature across the spectrum of loricate choanoflagellates currently described, that these can similarly manifest themselves with alternate morphologies, there will also be a need for reorganizing the basic loricate choanoflagellate nomenclature accordingly. However, lorica morphology will also here no doubt remain an overall fairly reliable morphotype marker, in accordance with what has so far also been evident from molecular studies (Carr et al., 2008; Nitsche et al., 2011; Nitsche 2014).

Having in mind the possible generic existence of pairwise associations of mutually different loricate choanoflagellate morphotypes, this will of course also over time be reflected in phylogenetic schemes. Due to the limited number of taxa that have been sequenced so far (Nitsche et al., 2016) these are yet far from conclusive, and it is way too early to use the tentative relationship patterns emerging to start pinpointing other possible cross specific relationships. The genus Stephanoeca is obviously polyphyletic and needs a reorganization in the future (Nitsche et al., 2011). Interestingly both S. apheles and S. cauliculata, the two 
species that are here reported to form part of combination loricas, have been sequenced and found to be only remotely related (Nitsche et al., 2011). At first sight this is perhaps surprising in as much as they are both here reported to associate with species of Acanthocorbis, a phenomenon which may otherwise be used as an argument in favour of expecting these species of Stephanoeca to group together in phylogenetic schemes. However, it is obvious that both $S$. apheles and S. cauliculata as well as A. campanula and A. haurakiana do pairwise deviate markedly in lorica morphology to the extent that the generic affiliations may be questioned based alone on morphological features. Sequence data of both A. campanula and A. haurakiana is obviously much in demand primarily with respect to supporting or rejecting the hypothesis forwarded here that unites these taxa in complex heteromorphic life histories that also involves species of Stephanoeca.

The finding of identical sequences of differently identified loricate choanoflagellate species will in most cases be immediately dismissed as erroneous. However, considering the circumstantial evidence of phase changes reported here, such cases should at least be corroborated or rejected based on further sampling. When collecting data for the paper recently published by Nitsche et al. (2016) we did in fact come across two examples of identical sequences from morphologically distinct taxa. These cases were at first omitted from the molecular phylogenies in Nitsche et al. (2016), and are now being subjected to repeated analyses.

If the possibility indicated in the material presented here that a loricate choanoflagellate may have distinct life cycle phases is accepted, it opens for fairly speculative possibilities. The Antarctic ice-biota community as analysed by Thomsen et al. (1997) differs significantly from the neighbouring pelagic community of loricate choanoflagellates. The two vastly different habitats (brine channels versus open water) have hardly any overlap in species and it therefore remains a possibility that the pelagic life forms are in fact connected with the ice- 
biota life forms through complex life cycles. It is difficult to think of a more profound habitat change to trigger the onset of a life cycle phase shift than what is experienced by cells being filtered from the water column during ice crystal formation to become incorporated into a forming ice sheet. If not accepting this option, the establishment of a recurrent and highly unique community of ice related loricate choanoflagellates will have to rely on the incorporation into newly forming sea ice of cells randomly surviving throughout the prolonged ice free season in the water column, at cell densities too low to be documented through standard procedures of imaging nanoflagellates.

Even though we are currently unable to present anything but circumstantial evidence demonstrating the existence of morphologically divergent phases in the life cycles of loricate choanoflagellates we are here presenting this material in the hope that this will lead to more observations of combination loricas from nature, or even better the observation of a similar phenomenon when studying cultured material. Genetic sequencing of the species involved will eventually be needed to provide a more definitive proof of the exact interrelationship of the species pairs across generic boundaries accounted for here.

\section{Acknowledgements}

We acknowledge the Univ. of Copenhagen for providing access to facilities at the Arctic Station, Qeqertarsuaq, and staff at the station for help in all possible ways. Thanks are due to the RV 'Ophelia’ crew for numerous trips to the 'Buoystation’ and to Naja Vørs, Lise Ewald Hansen and Niels Daugbjerg for contributing to the processing of these samples. 


\section{References}

Billard, C., 1994. Life cycles. In Green, J.C. and Leadbeater, B.S.C. (Eds) The Haptophyte Algae, Oxford University Press/Clarendon, pp167-186.

Carr, M., Leadbeater, B.S C., Baldauf, S.L., 2010. Conserved meiotic genes point to sex in the choanoflagellates. J. Eukaryot. Microbiol. 57, 56-65.

Carr, M., Leadbeater, B.S.C., Hassan, R., Nelson, M., Baldauf, S.L., 2008. Molecular phylogeny of choanoflagellates, the sister group to Metazoa. PNAS 105, 16641-16646.

Dassow, P.V, Montresor, M., 2011. Unveiling the mysteries of phytoplankton life cycles: patterns and opportunities behind complexity. J. Plankton Res. 33, 3-12.

Dayel, M.J., Alegado, R.A., Fairclough, S.R., Levin, T.C., Nichols, S.A., McDonald, K., King, N., 2011. Cell differentiation and morphogenesis in the colony-forming choanoflagellate Salpingoeca rosetta. Dev. Biol. 357, 73-82.

Espeland, G., Throndsen, J., 1986. Flagellates from Kilsfjorden, southern Norway, with description of two new species of choanoflagellida. Sarsia 71, 209-226.

Kamptner, E., 1941. Die Coccolithineen der Südwestküste von Istrien. Annal. Naturhist. Mus. Wien 51, 54-149.

Leadbeater, B.S.C., 1980. Four new species of loricate choanoflagellates from South Brittany, France. Cahiers Biol. Mar. 21, 345-353.

Leadbeater, B.S.C., 2015. The Choanoflagellates: Evolution, biology and ecology. Cambridge University Press. 315pp.

Levin, T., King, N., 2013. Evidence for sex and recombination in the choanoflagellate Salpingoeca rosetta. Current Biology 23, 2176-2180.

Moestrup, Ø., Thomsen, H.A., 1980. Preparation of shadow-cast whole mounts. In: Gantt, E. (Ed.) Handbook of Phycological Methods, Cambridge University Press, Cambridge, pp. 385-390. 
Nitsche, F., 2014. Stephanoeca arndti spec. nov. - first cultivation success including molecular and autecological data from a freshwater acanthoecid choanoflagellate from Samoa. Eur. J. Protist. 50, 412-421.

Nitsche, F., Carr, M., Arndt, H., Leadbeater, B.S.C., 2011. Higher level taxonomy and molecular phylogenetics of the Choanoflagellatea. J. Eukaryot. Microbiol. 58, 452-462.

Nitsche, F., Thomsen, H.A., Richter, D.J., 2016. Bridging the gap between morphological species and molecular barcodes - exemplified by loricate choanoflagellates. Eur. J. Protist. (in press).

Parke, M., Adams, I., 1960. The motile (Crystallolithus pelagicus Gaarder and Markali) and non-motile phases in the life history of Coccolithus pelagicus (Wallich)Schiller. J. Mar. Biol. Ass. U.K. 39, 263-274.

Thomsen, H.A., 1992. Plankton i de indre danske farvande. Havforskning fra Miljøstyrelsen 11. 340pp.

Thomsen, H.A., Larsen, J., 1992. Loricate choanoflagellates of the Southern Ocean with new observations on cell division in Bicosta spinifera (Throndsen, 1970) from Antarctica and Saroeca attenuata Thomsen, 1979, from the Baltic Sea. Polar Biol. 12, 53-63.

Thomsen, H.A., Buck, K.R., Chavez, F.P., 1991. Choanoflagellates of the central California waters: Taxonomy, morphology and species assemblages. Ophelia 33, 131-164.

Thomsen, H. A., Garrison, D. L., Kosman, C., 1997. Choanoflagellates (Acanthoecidae, Choanoflagellida) from the Weddell Sea, Antarctica, taxonomy and community structure with particular emphasis on the ice biota; with preliminary remarks on choanoflagellates from Arctic sea ice (Northeast Water Polynya, Greenland). Arch. Protistenkd. 148, 77114.

Thomsen, H. A., Østergaard, J. B., Hansen, L.E., 1991. Heteromorphic life histories in arctic coc colithophorids (Prymnesiophyceae). J. Phycol. 27, 634-642. 


\section{Figure legends}

Fig. 1. Maps of the collection sites; (A) West Greenland, Disko Bay, with the sampling area identified by a square, and (B) Kattegat with the position of the 'buoy-station' marked by an angular black dot.

Figs 2-7. TEM shadowcast whole mounts of West Greenland material showing combination loricas (Figs 2-6) involving Acanthocorbis campanula and Stephanoeca apheles, and a solitary cell of S. apheles (Fig. 7). Scale bar $=2 \mu \mathrm{m}$.

Fig. 8. Diagram illustrating the site specific and depth-related occurrence (relative abundance) in West Greenland waters at stations 1, 3-5, 8-9 of Acanthocorbis campanula (graph lines) and Stephanoeca apheles (squares). Samples yielding combination loricas are encircled.

Figs 9-10. TEM shadowcast whole mounts of West Greenland material showing solitary specimens of Acanthocorbis campanula. Notice (Fig. 10) the mixture of thin and thickened costal strips. Scale bar $=2 \mu \mathrm{m}$.

Figs 11-16. TEM shadowcast whole mounts of material from the Kattegat showing combination loricas (Figs 11-13) involving Acanthocorbis haurakiana and Stephanoeca cauliculata, and solitary cells of A. haurakiana (Figs 14-15) and S. cauliculata (Fig. 16). Scale bar $=2 \mu \mathrm{m}$.

Fig. 17. TEM shadowcast whole mount of $S$. cauliculata from the Kattegat. Scale bar $=2 \mu \mathrm{m}$. 


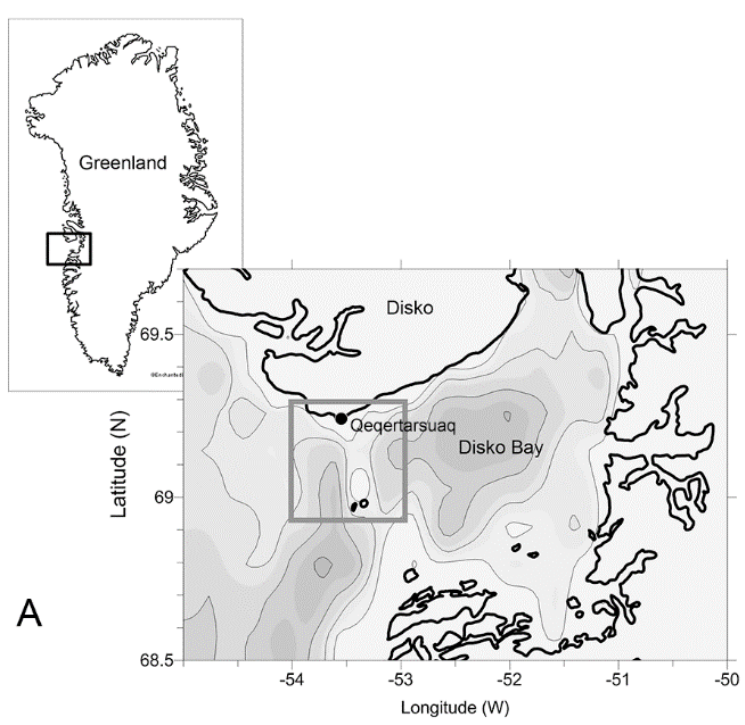

B

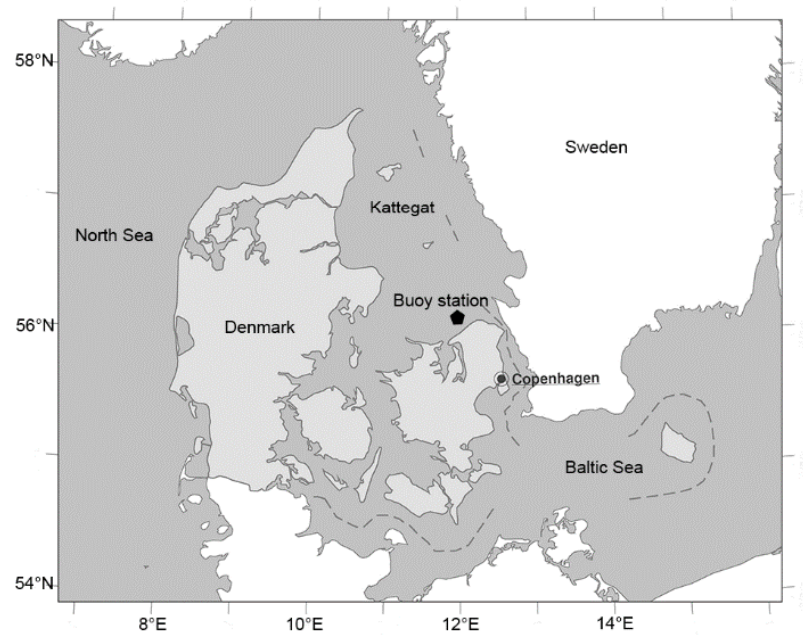

Fig 1 

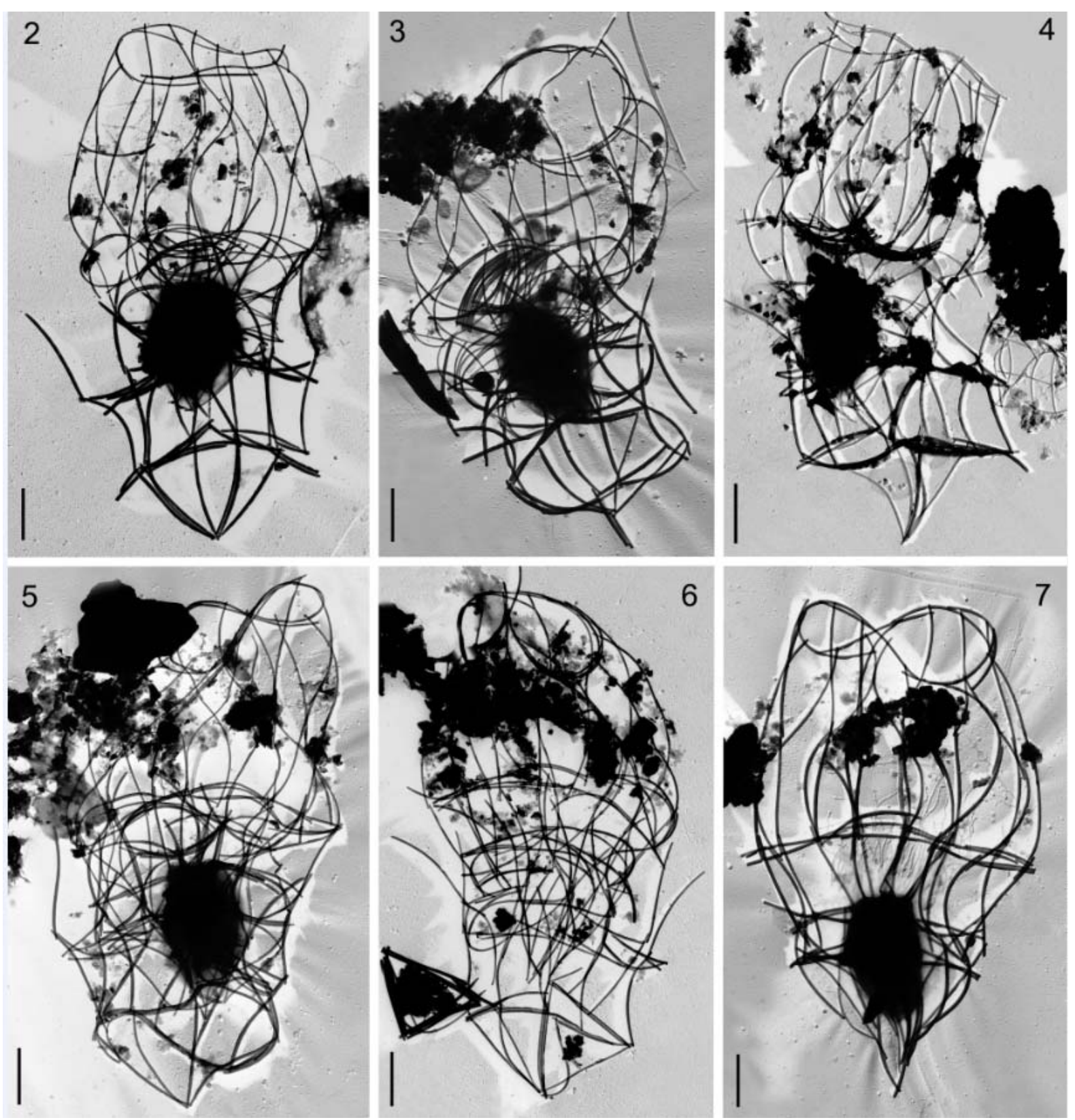

Fig 2-7 


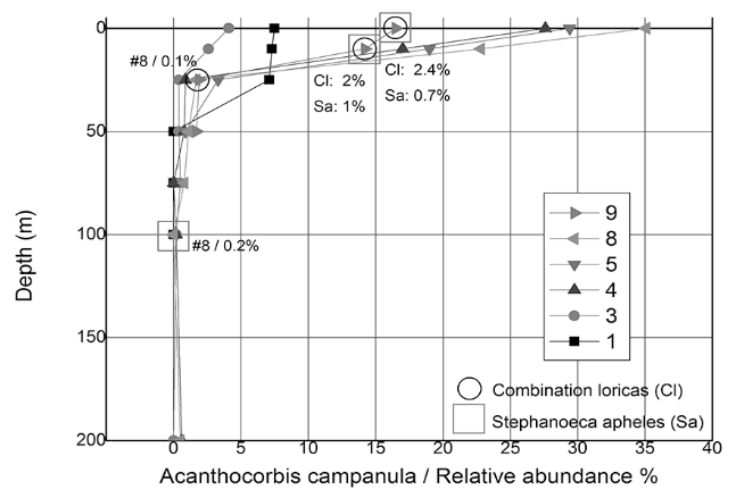

Fig 8 

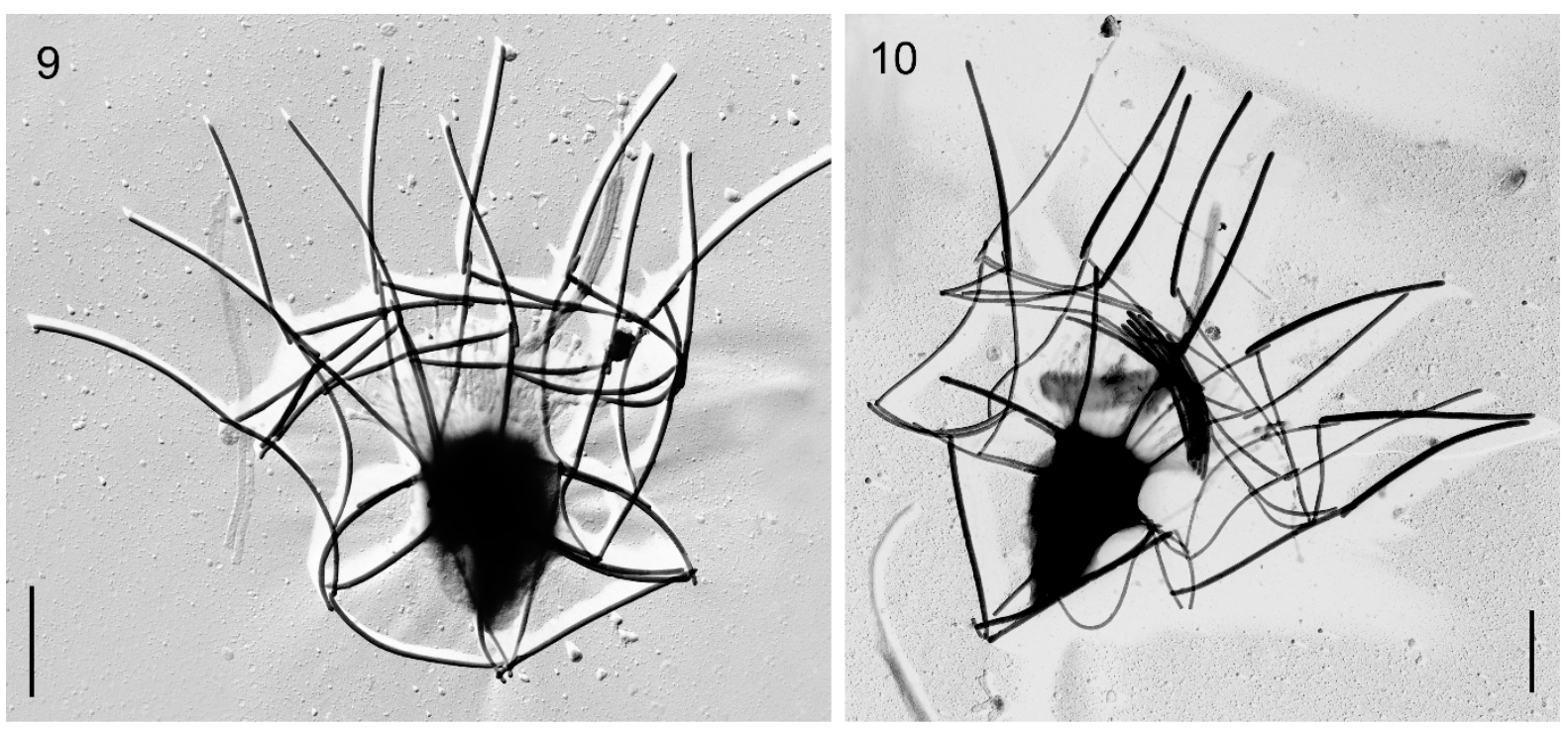

Fig 9_10 

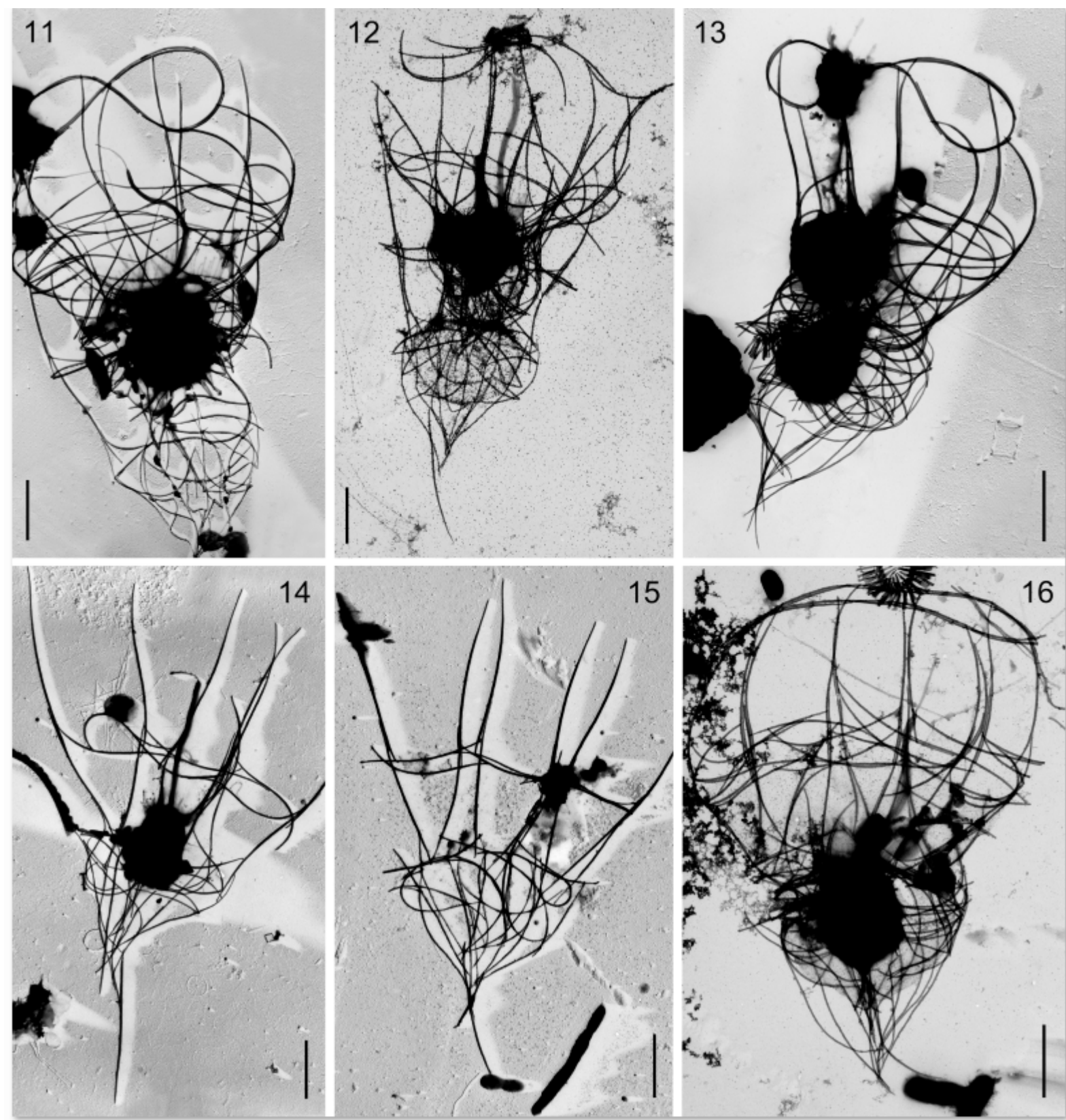

Fig 11_16 


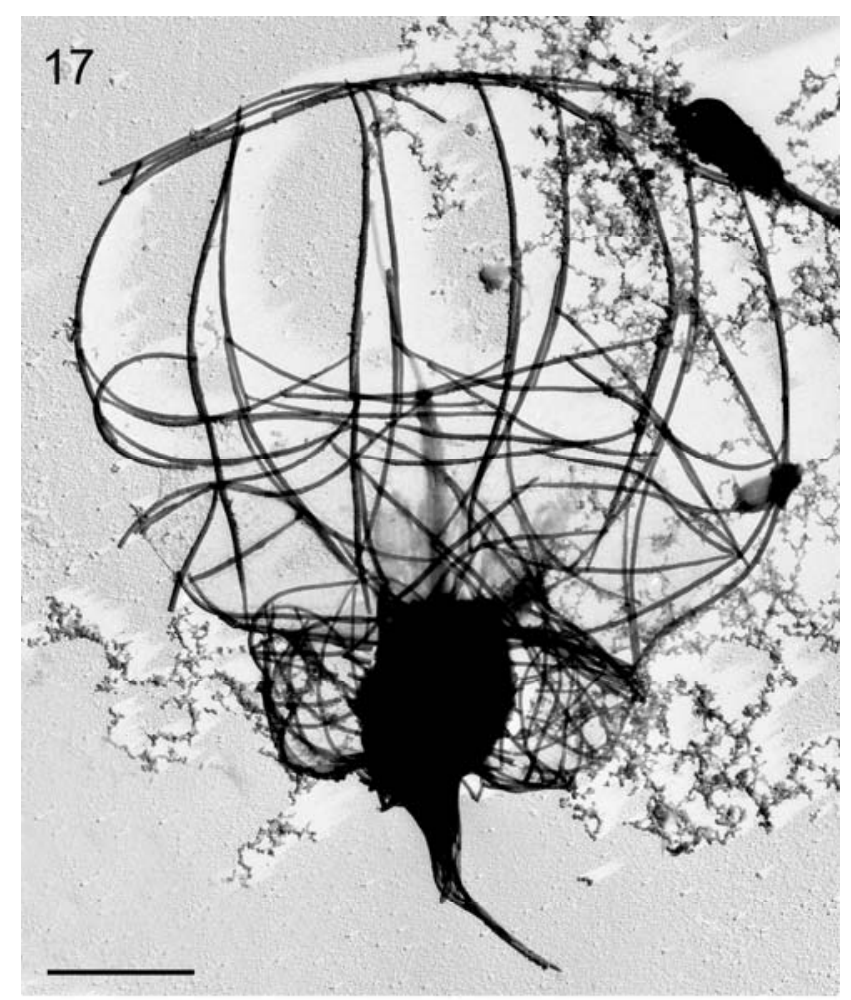

Fig 17 
Table 1. Lorica dimensions in Acanthocorbis campanula and Stephanoeca apheles when occurring as solitary cells and as a part of combination loricas. Material from West Greenland.

\begin{tabular}{|c|c|c|c|c|c|c|}
\hline & Phase & 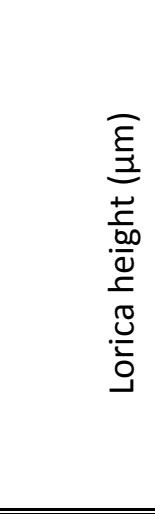 & 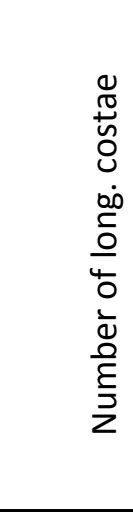 & 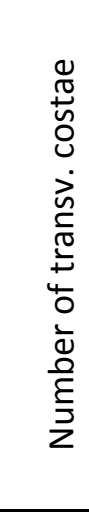 & 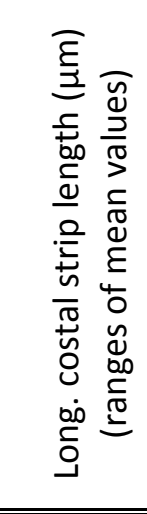 & 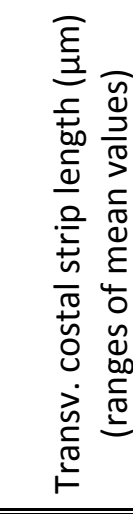 \\
\hline \multirow[t]{2}{*}{ Acanthocorbis campanula } & Solitary cell & $9.8-11.5$ & $10-12$ & 2 & $3.5-4.2$ & $2.7-3.4$ \\
\hline & Combination cell & 8.6-11.4 & 10 & 2 & $3.7-3.8$ & 3.1 \\
\hline \multirow[t]{2}{*}{ Stephanoeca apheles } & Solitary cell & $\begin{array}{c}13.9 \\
11.9-\end{array}$ & $12-15$ & 4 & 3.7 & 3.5 \\
\hline & Combination cell & 13.4 & $14-16$ & 3-4 & $4.2-4.6$ & $3.8-4.2$ \\
\hline
\end{tabular}

